\title{
On Some Problems of Teaching ESP
}

\author{
A. T. Knyazyan \\ Yerevan State University \\ Corresponding author. E-mail: annaknyazyan@ysu.am \\ Paper received 25.07.18; Accepted for publication 01.08.18.
}

\author{
https://doi.org/10.31174/SEND-PP2018-173VI71-03
}

\begin{abstract}
The subject matter of the present article is teaching ESP (English for Specific Purposes). The article gives general principles and methods of teaching English for professional communication at Universities. ESP has developed rapidly in the past thirty years and became very important in English language teaching. English has become an accepted language for international communication. It has also become a language of technology and commerce that gave birth to a new approach to language teaching which is called ESP. The English language today is a must for international specialists in all branches of economy, science, technology, tourism, art and sports. Nowadays the world has entered the era of advanced technology and international communication. Therefore, besides learning general English, students need to have an adequate ability so that they can communicate technical information clearly.
\end{abstract}

Keywords: ESP (English for Specific Purposes), professional communication, ESP learners, ESP teaching.

During the development of human history many changes took place not only in life and conditions of people but also in the sphere of language teaching. Today people want to learn and know the language not for pleasure only but for specific progress. Knowing English will help them to achieve their own goals and it can be a contributing factor to their professional recognition and career prospect. A good specialist cannot do without a foreign language. Every day different spheres of science go forward through the cooperation of specialists. The realization of this cooperation is based on the professional communication. That is why linguists focus their attention on the investigation of grammatical, lexical, stylistic means in various texts. Our purpose in writing this article is to share with ESP learners and educators the kind of insights that will enable them to become better ESP learners and teachers. The article is aimed to cover the issues of managing students' own language learning, develop English learning strategies and study skills guideline focusing on the basic academic competencies. This article is basically for ESP students and educators within the rages of it we'll try to come up with concrete suggestions to help the students as well as the teachers become more effective and successful language learners and teachers. The problem of learning the English language is very important today as it is socially demanded. The English language is needed as the most efficient means of information exchange of the people as it has become the internationally accepted language of almost all the fields of knowledge, for example, English for linguists, English for historians, English for chemists, English for biologists etc. Nowadays in order to fulfill the needs of people with inadequate proficiency in English different ESP courses have been introduced at universities. Thus, Carver differentiates three characteristics of ESP courses: 1) authentic material, 2) purposerelated orientation, 3) self-direction [1].

The ever-increasing political, economic, cultural and scientific contacts between different countries have brought us to a situation when the need for a language to serve the purpose of our international communication has become even more obvious. For well-known reason this very responsible role has been taken on by the English language which has now become one of the most important means of international communication. Hence the exceptional importance of English language learn- ing/teaching at present has widened its traditional scope and definitely acquired communicative orientation. If during the preceding stages of foreign language learning/teaching grammar questions have been considered to be pivotal, nowadays the direction has definitely changed towards developing the communicative skills of the learners. Before setting out to teach a foreign language the teacher must always have a clear-cut idea about what variety of the language his learners need to be taught. Thus, everything starts with the need-analysis for if we are not definite about the particular purpose of learning and teaching the language, we are outside the actual communicative context and our linguistic activity is confined to practicing formal rules and regularities of constructing speech. The learner's attempts to produce language "in general" bring him to a deadlock as far as professional international communication is concerned. To be able to learn and use a foreign language as a means of effective international communication the learner must begin by becoming acquainted with the basic language of his profession, the variety he can use for his specific purpose. It goes without saying that this makes the learning/teaching process more purposeful and as a result, it enables specialists from different parts of the world to become proficient in the register they need for discussing their professional subjects at different international conferences, in the pages of international publications, thus exchanging their professional experience with their colleagues in different countries and following the progress of their branch all over the world. LSP is based on natural human languages which undergoes certain changes as far as the choice of different linguistic means of expression is concerned, for the teaching of professional language presupposes the choice of a certain content which conditions the choice of lexical, grammatical, as well as communicative means. When the learner combines his best command of this variety of language with his extralinguistic knowledge of this or that professional sphere, he is sure to avoid any kind of misunderstanding in communication.

According to Hutchinson ESP is an approach to language teaching in which content and methods are based on the learners' reason of learning [3 p.19]. ESP is a register of English used in those spheres of professional knowledge which have their own deep and welldeveloped systems of notions. This variety of language is 
characterized by a definite conceptual orientation and corresponding limitation imposed upon the functioning of linguistic units on all levels. In ESP a line of research has been to identify the characteristic lexico-grammatical features and rhetorical patterns of particular genres. This has helped to reveal how texts are typically constructed and how they relate to their contexts of use through specific social purposes, as well as providing valuable input for genre-based teaching. The analysis of ESP texts is carried out on the phonetic, morphological, lexical and syntactic levels and this overall study of features of all linguistic levels should be considered to be one of the advantages of ESP teaching. The objectives of teaching ESP are definite and concrete. The aim of the learner is to have a good command of scientific register in the main practical skills. Once they are aware of the register, learners may gradually master different idiomatic varieties of a given ESP. However, they should definitely start with "restricted scientific English" as the basis of the register and build a good knowledge of it. Careful linguistic observations show that most often people spontaneously produce a restricted form of scientific English (when they participate in international conferences, meet foreign colleagues, talk about their research, answer questions, write abstracts and articles) which provide a reliable understanding between the participants in professional communication.

David Carver identifies three types of ESP: 1) English as a restricted language - is only used for specific contexts; 2) English for Academic (EAP) and Occupational Purposes (EOP); 3) English with specific topics [1].

So how to teach ESP? As far as the method of teaching ESP is concerned, it should be mentioned that methodologists have agreed to consider teacher-oriented language teaching insufficient and outdated, for it is now beyond suspicion that involving the learners in active work in class makes language teaching more effective and gives the teacher an opportunity to escape the danger of indulging in excessive talking class. Not infrequently one may go as far as to suggest that the learners actually take an active part in the teaching themselves, i.e. use the method of the so-called 'peer-tuition'. Nowadays the teachers and students are equipped with textbooks and manuals for all professions, written both by native speakers and foreigners who specialize in teaching this particular variety of English. The study of the material should be arranged in the form of a seminar on the basis of the so-called 'peertuition'- a method which gives the learners an opportunity to participate in the two-fold process of analyzing and synthesizing samples of optimal speech in English. The learners are expected not only to prepare the material under study before the seminar, but also to arrange it in such a way that it could be presented at the lesson in the form of special tasks and exercises made up by the students themselves. As any text is a unity of form and content, it must necessarily cover both - the content plane and the expression plane. The study of the content plane is the questions connected with the most difficult aspects of the text. The study of the expression plane includes: 1) translating words, word-combinations from the mother tongue into English; 2) translating words, wordcombinations from English into the mother tongue; 3) testing words, word-combinations in longer speech units, placing them in a fresh context.

ESP is a pedagogy for learners with professional, academic, and occupational communicative needs. This means that the ESP teachers must follow the imperative of specificity and they cannot be the consumers of materials. The ESP teachers must consider the relevance of studies to their own learners and conduct their own target situation analyses into local contexts. They should use such techniques as observations to discover every student's reaction to any assignments. This information should feed back into the design of every ESP courses.

The ESP teachers should collaborate with particular subject experts. The specialists provide both the ESP teachers and the students with insights into the practices that experts engage in [4]. The expert of a particular field should assist the ESP teacher to select authentic texts. It should be added in this connection that every student also brings to their ESP courses some knowledge of his specialist fields. It means that ESP teachers need to negotiate their courses with learners in order to promote relevant communicative activities in the classroom. So the ESP teachers assist the learners to activate their latent understandings. All in all, we have to provide more opportunities for using and interacting in English, and we must respect our students' rights and interests as individuals to exercise choice in their English language study. Involving students in individualized learning projects is just a way we may help them gain confidence in their ability to manage their own learning and move further along the road to becoming independent language learners.

In order to teach ESP effectively, the teacher should also know in what typical situation specialists need English for their professional communication. We teach ESP in order to make the students be able: 1) to read publications concerned with their subjects in order to be informed about new development in their profession; 2) to express their own ideas or the results of their research in a verbal form; 3) to give talks at scientific conferences; 4) to participate in professional discussions and meetings; 5) to hold in formal conversation with their foreign colleagues about different issues.

To prepare students for a future career and professional communication, the teacher should also equip them not only with theoretical basis, but with a set of essential academic skills which they could apply in their professional life. Unlike mechanical training in a special lexicon and translating numerous texts, an ESP content course is designed to teach fundamental concepts and terminology, to introduce specific literature and current issues in their fields, to solve typical problems and to develop professional skills. We know that scientific texts contain terminology. In this connection, the following question arises. Should the main effort of learners and teachers in mastering a certain ESP be focused on terminology? The answer is that special words or terms do not present a significant difficulty for specialists in a given professional sphere. The terms are closely connected with conceptual field of their subject area and are usually more familiar to ESP learners than to their ESP teachers. That is why for ESP learners the terminology is the easiest part of the vocabulary. And that ESP is not confined merely to teaching terminology. 
Some people think that to find out what students actually require, one should have a complex test with relevant questionnaires. We believe, however, that it is not difficult for a teacher to understand the objective situation and formulate the aims of ESP learners. Consequently, the main linguistic skills the learners should acquire and master in the course of studying ESP are the following:

- reading various scientific texts in order to retrieve necessary information;

- speaking and writing on professional subjects;

- making reports and comprehending oral speech.

All these skills are quite obvious. These general principles or methods of teaching consist of making the students memorize words, word-combinations and other recurrent linguistic elements, listen to recordings, translate from one language into another for better understanding the content and establishing the equivalents in both languages. Since the skills of ESP and the languages are identical, the essential difference between them is not the skills mentioned above, but the variety of language people use while speaking, writing, reading and listening in everyday situations and using a foreign language for professional communication.

We should confess that the support of a teacher is a very important factor in the success of individualized learning. According to Lee, Benson and Voller the role of the teacher is promoting autonomous learning [5;2] Tremendous efforts were needed on the part of some outstanding scholars to persuade those concerned that the only possible approach to teaching EFL (English as a Foreign Language) consists in restricting it to a particular register of speech which could after being properly taught, be used by the speakers as "the tool of their trade".

The mastering of the language is necessary not only for communication with people round the world but also for developing professionally. To study effectively in Univer- sity and to gain ground in English, it is essential that all the students have the following academic competences:

- Reading - comprehend topic sentences and subordinate ideas, scan and skim reading material, identify the author's attitude and point of view etc.

- Writing - generate ideas about the topic of writing, organize, relate ideas and develop the piece of writing logically and structurally, use verb forms correctly, develop summarizing and paraphrasing skills etc.

- Speaking and listening - comprehend the main ideas in live or taped lectures, ask and answer questions, exchange ideas during discussions etc.

- Reasoning - identify and solve problems, draw conclusions, make generalizations etc.

- Studying - set goals along with the course objectives, comprehend, analyze, summarize, report the main ideas from different academic sources etc.

The essential difference between the skills of ESP and the language is the variety of language people use while speaking, writing, reading and listening in everyday situations and using a foreign language for professional communication. The goal involves the following tasks: 1) mastering terminology and linguistic realities; 2) acquaintance with the main features of stylistics and organization of modern English-language discourse; 3) formation of skills and abilities of oral and written communication in the field of scientific communication. As essential difference between teaching ESP and teaching general English is the kind of language which must be used as the target at every level of teaching ESP.

So, it is worth remembering that we cannot really teach a language, we can only create conditions in which it will develop spontaneously in the mind in its own way. We shall never improve our ability to create such favorable conditions until we understand more about the ways that make the learners study well.

\section{REFERENCES}

1. Carver D. Some propositions about ESP // The ESP Journal / 3. Hutchison T., \& Waters A. English for specific purposes / Carver D.// 1983, 2, pp.131-137.

2. Benson P. \& Voller P. Autonomy and Independence in Language Learning/ Benson P. \& Voller P.// London: Longman, 1997.

Hutchison T., \& Waters A.// Cambridge: CUP, 1987.

4. Johns A. M. Text, role and context: Developing academic literacies /Johns A. M.// Cambridge: CUP, 1997.

5. Lee I. Supporting greater autonomy in language learning //ELT Journal/ Lee I. // 52,4,pp. 282-89 